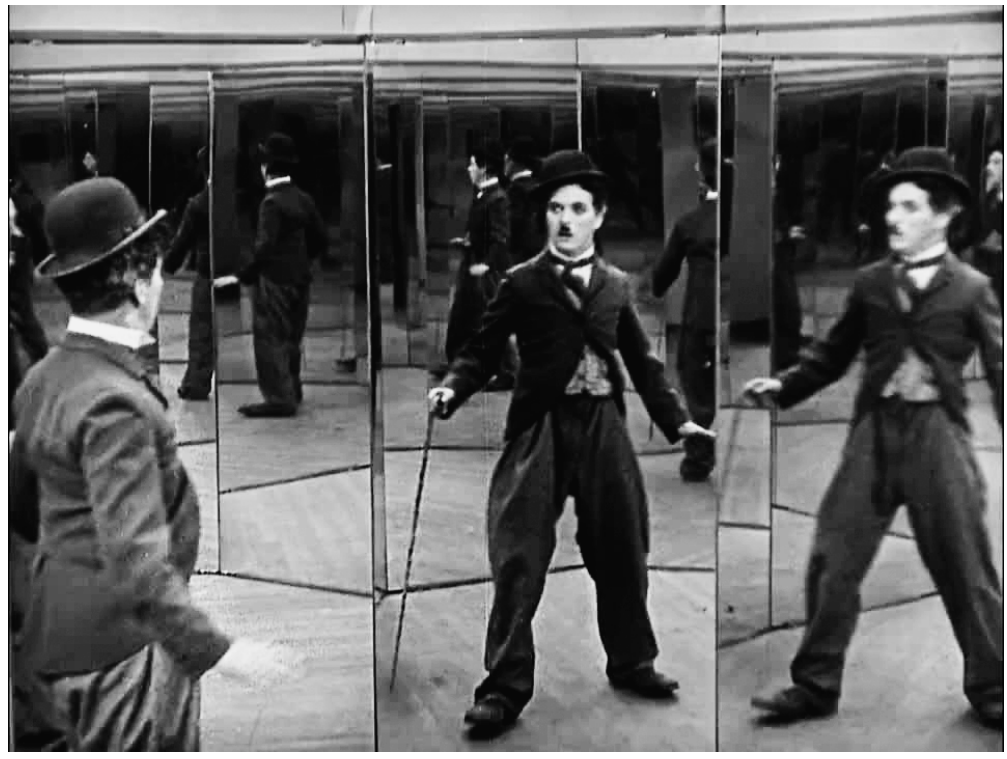

Charlie Chaplin. The Circus. 1928. 


\section{Frankfurter Slapstick: Benjamin, Kracauer, and Adorno on American Screen Comedy}

\section{STEVEN JACOBS AND HILDE D'HAEYERE}

It has long been noted that key figures of the European avant-garde of the interwar years, including many leading Dadaist, Surrealist, and Constructivist artists, greatly admired American slapstick comedies of the 1910s and '20s.1 Although these artists had diverse artistic agendas, their fascination with slapstick comedy tended to spring from similar preoccupations. First, the films of Mack Sennett, Charlie Chaplin, Buster Keaton, Harold Lloyd, and Harry Langdon, among others, were seen as examples of a pure cinema founded on essential cinematic qualities such as speed, motion, and rhythm. Second, for many members of the avant-garde, slapstick cinema responded adequately to the logic of mechanization, which they, too, sought to engage. Slapstick films not only reflected the keen interest in (absurd or unruly) machines, trains, motorcycles, airplanes, and cars; they were themselves products of industrial modernity. Mack Sennett's Keystone Film Company, for example, was one of the first to produce films according to the logic of serial manufacture, industry standards, and efficiency-induced division of labor. ${ }^{2}$ Third, the slapstick tradition brought an absurd reality to the fore, in which the laws of gravity, inertia, logic, and commerce were suspended and everyday objects mysteriously came to life, shifted shapes, and were transformed.

Precisely these aspects of slapstick cinema also attracted Walter Benjamin, Siegfried Kracauer, and Theodor W. Adorno in their investigations of the relationships between industrial capitalism and visual culture. As Miriam Bratu Hansen has demonstrated in detail, Frankfurt critical theory developed a philo-

1. See, for instance, Sabine Hake, "Chaplin Reception in Weimar Germany," New German Critique 51 (1990), pp. 87-111; Dorothee Kimmich, ed., Charlie Chaplin: Eine Ikone der Moderne (Frankfurt am Main: Suhrkamp, 2003); Amy Sergeant, "Dancing on Fire and Water: Charlot and L'Esprit Nouveau," in Slapstick Comedy, ed. Tom Paulus and Rob King (London: Routledge, 2010), pp. 193-206; Jennifer Wild, The Parisian Avant-Garde in the Age of Cinema, 1900-1923 (Berkeley: University of California Press, 2015), pp. 225-77; and Owen Hatherley, The Chaplin Machine: Slapstick, Fordism, and the Communist Avant-Garde (London: Pluto Press, 2016).

2. See Rob King, The Fun Factory: The Keystone Film Company and the Emergence of Mass Culture (Berkeley: University of California Press, 2009); and Janet Staiger, "Dividing Labor for Production Control: Thomas Ince and the Rise of the Studio System," Cinema Journal 18, no. 2 (Spring 1979), pp. 16-25.

OCTOBER 160, Spring 2017, pp. 30-50. (C) 2017 October Magazine, Ltd. and Massachusetts Institute of Technology. 
sophical critique of modernity in which cinema played a key role. ${ }^{3}$ Building on the work of Hansen, which deals with these thinkers' writings on cinema in its broadest sense, this article focuses on their views of slapstick film. Scrutinizing the writings of Benjamin, Kracauer, and Adorno for references to American slapstick films (or the Groteske, as they were generally called in German), we show not only the similarities in their patterns of thinking but also their subtle differences. Moreover, by reconnecting their philosophical ideas to specific scenes and tropes in the films that might have inspired them, we also situate such ideas historically, drawing attention to the critics' anachronistic interpretations, in which characteristics typical of the slapstick cinema of the 1910s were projected onto Chaplin's films of the late 1920s and '30s. As a result, the subversive and utopian aspirations that slapstick cinema seemed to offer were increasingly imbued with a feeling of nostalgia that marked the rediscovery and recycling of slapstick comedy after World War II.

Mack Sennett.

Mabel's Married Life. 1914.

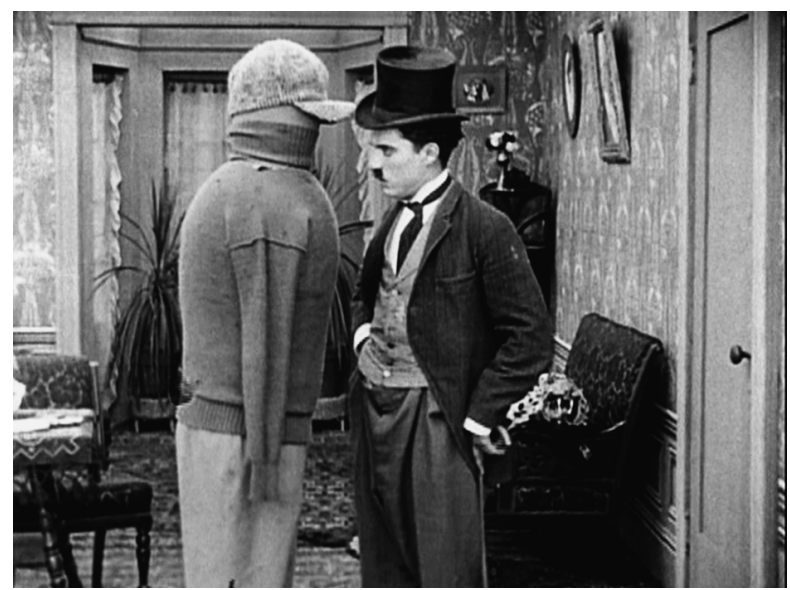

Benjamin: The Shocks and Thrills of Slapstick Cinema

For Adorno, Benjamin, and Kracauer, film is a symptomatic phenomenon through which to understand modernity and its effects on art and culture. Industrial capitalism had not only given rise to new economic and social relations, it also spawned new ways of life and new means of experiencing the world. Walter Benjamin, in particular, states in several of his texts of the late 1920 s and '30s that cinema developed in tandem with a new reality characterized by the constant exposure to shocks as a result of the mechanization of labor, urban traffic, the increasingly rapid circulation of capital, and industrial

3. Miriam Bratu Hansen, Cinema and Experience: Siegfried Kracauer, Walter Benjamin, and Theodor W. Adorno (Berkeley: University of California Press, 2012). 
warfare. Following Georg Simmel, Benjamin stressed the link between the overstimulation of the senses induced by modern technology and the development of a mass culture with a strong preference for thrills. A veritable entertainment industry of world fairs, panoramas, and amusement parks had emerged in the nineteenth century, alongside a panoply of new viewing apparatuses. It was against this background that cinema developed at the end of the century and, in its earliest form, aimed to satisfy a desire for spectacle. ${ }^{4}$ According to Benjamin, cinema was therefore complicit in the process of sensory numbness that industrialization had set in motion. He argued that film, as the medium of choice in the age of technological reproducibility, would sound the death knell for the traditional concept of art and the aura of a unique artwork. At the same time, however, film could be enlisted to teach people the emotions and attitudes needed to survive in a world increasingly determined by the speed of machines. Through medium-specific techniques like extreme close-ups, montage, and slow-motion photography, cinema encouraged audiences to look anew at the world around them and enabled them to prepare for a technologydriven world. Cinema tapped into the exploration of the "optical unconscious" by generating new types of perception, experience, and collective forms of subjectivity. In so doing, film possessed both therapeutic and educational functions for Benjamin, as well as an emancipatory dimension. ${ }^{5}$

Somewhat surprisingly, Benjamin calls not only on Soviet cinema, with its relevant feats of expressive imagery and defamiliarizing montage, but also on Chaplin comedies as examples of emancipatory cinema. In several texts written in the late 1920s, Benjamin even mentions Soviet cinema and slapstick comedy in the same sentence, praising their unconventional narrative structures. "Chaplin was the first (and the Russians have followed his example) to construct a film with a theme and variations-in short, with the element of composition," Benjamin writes, noting that "all this stands in complete opposition to films based on action and suspense." 6 Uninterested in traditional storytelling with its narrative arc, slapstick cinema utilizes a succession of routines with repetitions and variations, inspiring Soviet directors to conceive of films as concatenations of shock moments. Benjamin goes on to link slapstick cinema and Eisenstein's films explicitly to the horrors of modern technology:

The superiority of the cinema of the Russian Revolution, like that of the American slapstick comedy, is grounded on the fact that in their different ways, they are both based on tendencies to which they con-

4. Ben Singer, Melodrama and Modernity: Early Sensational Cinema and Its Context (New York: Columbia University Press, 2001).

5. Hansen, Cinema and Experience, p. 171.

6. Walter Benjamin, "Rückblick auf Chaplin" (1929), in Gesammelte Schriften 3 (Frankfurt am Main: Suhrkamp, 1989), pp. 157-59; published in English as "Chaplin in Retrospect," in The Promise of Cinema: German Film Theory 1907-1933, ed. Anton Kaes, Nicholas Baer, and Michael Cowan (Berkeley: University of California Press, 2016), pp. 398-400. 
stantly recur. For the slapstick comedy is tendentious too, in a less obvious way. Its target is technology. This kind of film is comic, but only in the sense that the laughter it provokes hovers over an abyss of horror. The obverse of a ludicrously liberated technology is the lethal power of naval squadrons on maneuver, as we see it openly displayed in Potemkin. ${ }^{7}$

As Soviet directors such as Eisenstein, Meyerhold, Kuleshov, and Pudovkin found in American slapstick comedy inspiration for their own experiments with biomechanics, Benjamin sees Chaplin as a phenomenon that internalized the logic of the machine, connecting the mechanics of the conveyor belt to the machinery used to edit film. ${ }^{8}$ For Benjamin, Chaplin embodies the fragmenting effects of technology in his very physique, as though his body were the result of mechanical production and his movements dictated by the principle of industrial assembly: "Whether it is his walk, the way he handles his cane, or the way he raises his hatalways the same jerky sequence of tiny movements applies the law of the cinematic image sequence to human motorial functions."9 Like Kracauer, Viktor Shklovsky, Jean Epstein, Franz Kafka, and Bertolt Brecht, Benjamin recognizes in Chaplin a mechanical physicality, and he defines that quality as "cinematic."10 The most-cited illustration of Chaplin's machine-like qualities, of course, is his feature film Modern Times (1936), which was released about the time Benjamin wrote the second version of his essay "The Work of Art in the Age of Technological Reproducibility" that developed his ideas on Chaplin.11 In the film, the Tramp's body quite literally merges with the mechanical intestines of a camera-like circuit of cogs and wheels. But the "mechanical qualities" of Chaplin's movement can be found much earlier, from his fight with a boxing dummy in Mabel's Married Life (1914), the very first film based on a script idea by Chaplin, to The Circus (1928), in which the Chaplin character camouflages himself as a mechanical doll that stands outside a hall of mirrors.

7. Walter Benjamin, "Erwidering an Oscar A.H. Schmitz" (1927), in Gesammelte Schriften 2, no. 2, p. 753; English translation in Kaes, Baer, and Cowan, The Promise of Cinema, p. 358.

8. See the (then unpublished) notes that Benjamin made for his essay on "The Work of Art in the Age of Mechanical Reproducibility," published in Gesammelte Schriften 1, p. 1040. Benjamin had previously written on Chaplin in the "Chaplin" entry (n.d.) of "Charakteristiken und Kritiken," in Gesammelte Schriften 6, pp. 137-38; and "Rückblick auf Chaplin" (1929), in Gesammelte Schriften 3, pp. 157-59.

9. Walter Benjamin, "Varia zum Kunstwerk," in Gesammelte Schriften 1, p. 1047.

10. See Franz Kafka, "Über Charlie Chaplin," in Kimmich, Charlie Chaplin: Eine Ikone der Moderne, p. 41; Viktor Shklovsky, Literature and Cinematography (1923), trans. Irina Masinovsky (Champaign: Dalkey Archive Press, 2008), pp. 64-67; Jean Epstein, "Magnification," in French Film Theory and Criticism: A History/Anthology 1907-1939, ed. Richard Abel (Princeton: Princeton University Press, 1993), pp. 235-40; Paul Flaig, "Brecht, Chaplin, and the Comic Inheritance of Marxism," in The Brecht Yearbook / Das Brecht-Jahrbuch 35 (2010), pp. 3-22.

11. See Hansen, Cinema and Experience, pp. 163-82; and Esther Leslie, Hollywood Flatlands: Animation, Critical Theory and the Avant-Garde (London: Verso, 2002), pp. 80-122. 
Benjamin goes further than other critics, however, arguing that Chaplin and other American Groteskfilme (as well as Mickey Mouse cartoons) have a therapeutic effect. ${ }^{12}$ Struggling with machines, motorized traffic, crowds, skyscrapers, and other paraphernalia of urban modernity, slapstick-film comedians show us how to cope with the dangerous tensions caused by mechanization. By interiorizing the logics of the machine and treating mechanical movement and mechanized behavior as comedy material, they neutralize the frightening aspects of modern technology. Furthermore, the frenetic movements of Chaplin and Mickey Mouse reveal irrational aspects of the regime of rationalization. Slapstick films and Disney cartoons may have been products of industrial efficiency and mass consumption, but they also undermined the disciplinary force of the industrial regime through orgies of destruction, magic, and parody. In slapstick comedy and in Disney's early creations, Benjamin identifies a playful interaction with reality13_one that was also revered by the slapstick enthusiasts among the avant-garde such as the Surrealists or a modernist architect such as Karel Teige, who attempted to confer a poetic value on industrially produced consumer objects. Chaplin's films not only respond to the machine-age logics of speed and mechanization, they also testify to the importance of play and its subversive power. Benjamin describes Chaplin's character of the Tramp as "one of the first Trockenwohner [provisional inhabitants] of the new spaces of action that emerged with film," evoking a figure that employs unprecedented ways to explore novel conditions. ${ }^{14}$ Interestingly, the original term for these spaces of action (Spielräumen) also translates as "rooms for play." This playful approach culminates in the phenomenon of the gag: an exaggerated response or absurd action that punctuates the system of narrative causality in an anarchist-comical way. ${ }^{15}$

Slapstick jokes target the physical laws pertaining to gravity, motion, or mass as much as the rules of narrative logic. Like Eisenstein, Benjamin was impressed by the "plasmatic" qualities of the early Disney movies, whereby characters have the

12, Walter Benjamin, "Das Kunstwerk im Zeitalter seiner technischen Reproduzierbarkeit (Zweite Fassung)," in Gesammelte Schriften 7.1, p. 377. Kracauer, too, compares Chaplin and Mickey Mouse, describing Disney's creation as the "two-dimensional next of kin" of the Tramp. See Siegfried Kracauer, Theory of Film: The Redemption of Physical Reality (1960) (Princeton: Princeton University Press, 1997), p. 281; and John Canemaker, Felix: The Twisted Tale of the World's Most Famous Cat (New York: Da Capo Press, 1996), p. 102. Chaplin admired cartoon figures for their mechanical makeup; he envied the fact that they never needed to pause for breath and thus had absolute and perfect timing. In fact, the mechanical qualities of Chaplin as cartoon figure inspired Fernand Léger's film Ballet mécanique (1924), in which his Cubist Charlot figure is reduced to a collection of wooden puzzle-like pieces that feature the individual characteristics of the Tramp: a mustache, bowler hat, and walking stick, which come to life assembled in stop-motion animation.

13. Benjamin, "Das Kunstwerk im Zeitalter seiner technischen Reproduzierbarkeit (Zweite Fassung)," pp. 350-84.

14. Ibid., pp. 377-78.

15. Hansen, Cinema and Experience, pp. 193-94. 


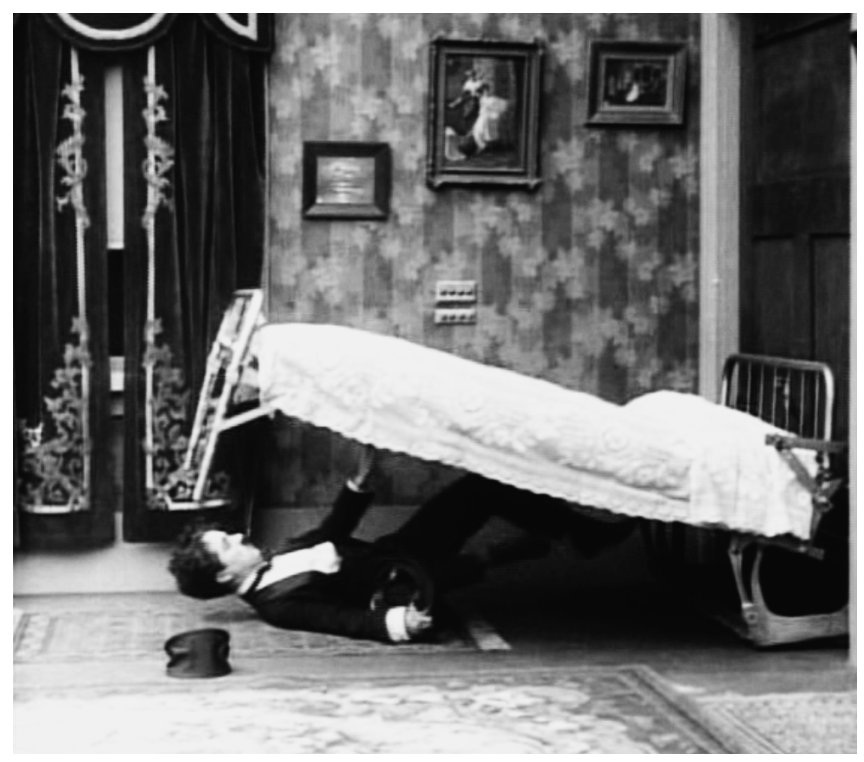

Charlie Chaplin. One A.M. 1916.

opportunity to "dynamically assume any form."16 In slapstick films, too, objects come to life and human beings transform into objects. Typical of slapstick's physical and aggressive humor are scenes in which human bodies are destroyed-for example, by a steamroller-and then miraculously recover. Such absurdities, however, harbor something much darker, calling to mind the effects on human bodies battered by industrial warfare and resulting in a particularly modern sense of selfalienation. Benjamin compares Chaplin's films to the works of Kafka and suggests that the way in which Chaplin and Co. assimilate the fragmenting and alienating effects of modern technology on the human body into their acting style even provides a key to an understanding of Kafka. ${ }^{17}$

Benjamin's emphasis on the physicality, speed, and immediacy of slapstick film implies a tactile and visceral approach to cinema. The visual shock of what a French critic already in 1916 described as the "Americano-epileptic invasion of comedies" has a liberating impact, triggering laughter on a purely physical level that transcends mere sadistic fun. ${ }^{18}$ "In his films, Chaplin appeals both to the most international and the most revolutionary emotion of the masses: their laughter," Benjamin writes in 1929.19 As Jennifer Wild notes, the laughter that

16. $\quad$ Sergei Eisenstein, Eisenstein on Disney (New York: Methuen, 1988), p. 21.

17. Walter Benjamin, "Aufzeichnungen” 4, in Gesammelte Schriften 2, p. 1198.

18. Wild, The Parisian Avant-Garde in the Age of Cinema, p. 254.

19. Benjamin, "Rückblick auf Chaplin," pp. 157-59 (in Kaes, Baer, and Cowan, The Promise of Cinema, pp. 398-400). 


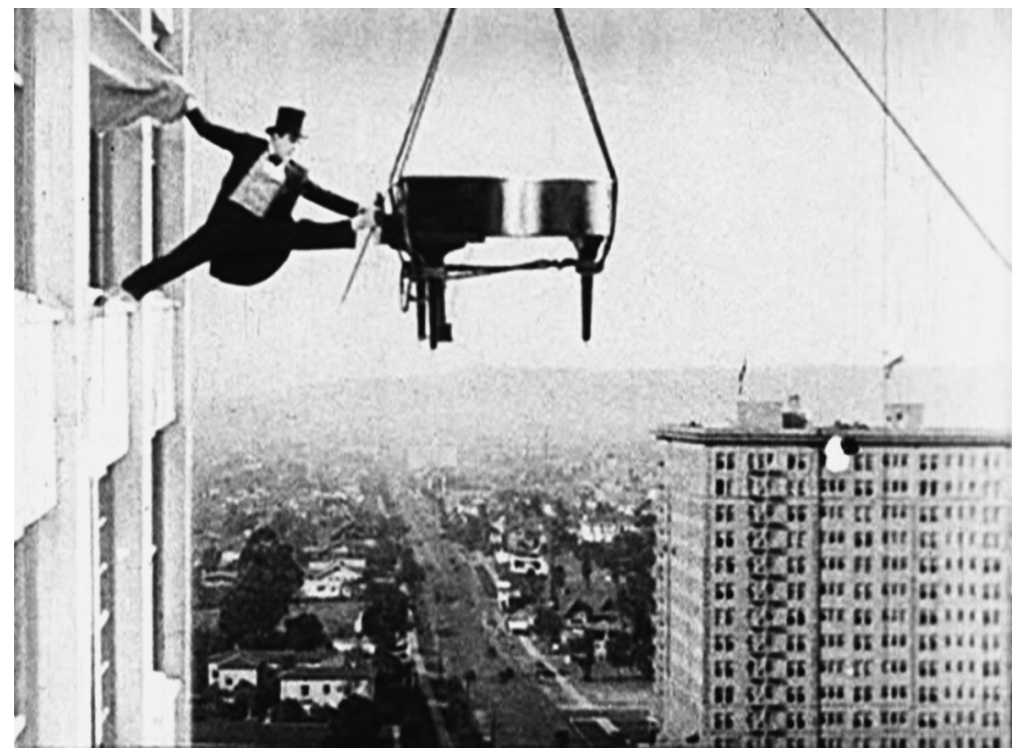

Roscoe Arbuckle. Fool's Luck. 1926.

Chaplin induced among European audiences was "of such a profound nature that it bypassed codes of social civility." 20 For Benjamin, such transgressive laughter creates a new kind of collective spectatorship with revolutionary potential, resulting in what Wild calls "a collective experience of rupture" that dissolves "the unified integrity of civilized spectators into a mass of uncontrollable bodies."21 Furthermore, shaking up the audiences through viscerally experienced, collective laughter, slapstick films and cartoons are, according to Miriam Hansen, an "immunization" against the mass psychoses and sadistic fantasies of industrial modernity, as they relieve "destructive unconscious energies."22 For Benjamin, this collective laughter could be mobilized as an antidote against the dangers of fascism. In a note from 1934, he compares Chaplin with Hitler years prior to the comedian's famous caricature of the Führer in The Great Dictator (1940). Benjamin describes the actor as "a plowshare that cuts through the masses" and, in so doing, sets laughter free. 23 This metaphor does not merely describe the value of comedy as relief in an audience beset by everyday worries.

20. Wild, The Parisian Avant-Garde in the Age of Cinema, p. 251.

21. Ibid., p. 252. Wild argues that it was precisely this laughter that made Chaplin so attractive in the eyes of the Dadaists.

22. Hansen, Cinema and Experience, p. 99.

23. Walter Benjamin, "Hitlers herabgeminderte Männlichkeit," fragment 75 from the "Fragmente vermischten Inhalts," in Gesammelte Schriften 6, p. 103. 
Its precise use of words-die Pflugschar, die durch die Massen geht-ascribes more aggressively activating powers to comedians, likening them to cutting blades that churn up the soil to upend the current state of affairs. Particularly noteworthy is a passage from the third version of Benjamin's "Work of Art" essay, in which he discusses the changing relationship of the masses to art as a result of the mechanical reproduction and dissemination of images of artworks. Benjamin notes that "the reactionary attitude, for example toward a Picasso painting," can change into "the most progressive reaction toward a Chaplin movie."24 For Benjamin, the individual contemplation of a unique piece of high art does not measure up to the power that the wide distribution of Chaplin films has.

In his emphasis on the explosive power and educational force of the gag, Benjamin underestimates the affirmative and conservative reflex to which slapstick jokes also testify. Certainly gags, laughter, and humor can also be seen as mechanisms that channel the irritations, frustrations, and fears that were unleashed by industrial modernity and, as such, sustain the precarious balance of the social status quo. Ridicule does not only have the power to resist and inflame, it also is an oft-used means to tame and contain social tensions. ${ }^{25}$ In this respect, authors such as Miriam Hansen and Esther Leslie have noted that Benjamin's references to Chaplin and Mickey Mouse are mainly developed in the second version (1936) of his text on mechanical reproduction. In the third, most widely published, 1939 version of the famous essay, the references to Chaplin were significantly curtailed and Mickey Mouse is absent from the text altogether. ${ }^{26}$ These alterations, no doubt, resulted from Benjamin's correspondence with Adorno, who was more skeptical about cinema's critical and revolutionary potential.

Kracauer: Slapstick between Mass Ornament and Contingency

Slapstick cinema also attracted the attention of Siegfried Kracauer, who published two canonical books on the medium just after WWII, although his views had largely been formulated prior to the conflict. $27 \mathrm{He}$ also authored many short texts about film: Of his almost two thousand essays, articles, and reviews, nearly seven

24. Walter Benjamin, "Das Kunstwerk im Zeitalter seiner technischen Reproduzierbarkeit (Dritte Fassung)," in Gesammelte Schriften 1, pp. 496-97.

25. See Alan Bilton, Silent Film Comedy and American Culture (New York: Palgrave MacMillan, 2013); and Robert Sklar, Movie-Made America: A Cultural History of American Movies (New York: Vintage Books, 1994), p. 105.

26. Hansen, Cinema and Experience, pp. 163-82; Esther Leslie, Hollywood Flatlands: Animation, Critical Theory and the Avant-Garde (London: Verso, 2002), pp. 80-122.

27. See Siegfried Kracauer, From Caligari to Hitler: A Psychological History of the German Film (Princeton: Princeton University Press, 1947); and Theory of Film: The Redemption of Physical Reality (1960; Princeton: Princeton University Press, 1997). 
hundred are devoted to film, filling three volumes of his collected works. ${ }^{28}$ Like Adorno, Kracauer considers the new medium to be a machine-made form of creativity that produces clichés via an assembly-line process, illustrating the implementation of Fordist production methods in the world of leisure and entertainment.29 In his famous essay on the "mass ornament," Kracauer uses the popular phenomenon of chorus girls to demonstrate how the laws of industrial capitalism determine mass culture and how entertainment itself is increasingly subject to the logic of mechanization. ${ }^{30}$ After a numbing day job at the factory, the worker seeks leisure experiences that have been created via the same factory-like processes that dictate the organization of labor.

Kracauer was fully aware of the dystopian and anti-democratic dimensions of mass media but was nonetheless convinced that film possessed a utopian potential capable of creating an alternative public sphere that paves the way for the democratization of culture. Film not only offers the masses an opportunity for self-representation but also facilitates the restructuring of human experience. Precisely because film shows the impact of modern technology on the senses-through specific processes such as framing and editing-it helps people to cope with an unprecedented reality. The new medium corresponds to the logic of Zerstreuung, or "distraction": a new, legitimate form of aesthetic experience that can provide an alternative to outdated forms of perception like the "bourgeois" contemplation of what Benjamin describes as the "aura" of an artwork. 31 Film, with its alienating effects, enables us to look differently at objects. It can offer a response to the commodity fetishism to which capitalism subjects all things, thereby saving them from reification.

Kracauer, like Benjamin, seems utterly convinced that the antidote to mass culture could be found within mass culture itself. Yet he had much more specific notions than Benjamin of the cinema's utopian dimensions. Whereas Benjamin ascribes an emancipatory power to film in general, Kracauer stresses the importance of specific cinematic languages and distinct genres. At its best, Kracauer argues, film allows the world to communicate for itself and grants space to the unpredictable, accidental, and ephemeral - the subtle shifts of light, the small events in the margin, the chaos of the urban masses, life on the streets, and so on.

28. See Siegfried Kracauer, "Kleine Schriften zum Film," in Werke 6.1, 6.2, and 6.3 (Frankfurt am Main: Suhrkamp, 2004). See also Miriam Hansen, “With Skin and Hair': Kracauer's Theory of Film, Marseille 1940," Critical Inquiry 19 (Spring 1993), pp. 437-69; and Johannes von Moltke and Kristy Rawson, eds., Siegfried Kracauer's American Writings: Essays on Film and Popular Culture (Berkeley: University of California Press, 2012).

29. See for example the well-known essay "Little Shop Girls Go to the Movies" (1927), included in Siegfried Kracauer, The Mass Ornament: Weimar Essays (Cambridge, MA: Harvard University Press, 1995), pp. 291-306.

30. Siegfried Kracauer, "The Mass Ornament (1927)," in The Mass Ornament, pp. 75-88.

31. See Siegfried Kracauer, "Cult of Distraction (1926)," in The Mass Ornament, pp. 323-28. 
Consequently, Kracauer despises the studio-bound films of Expressionism, which adhered to screenplays and were excessively theatrical. Instead, he admires the pioneers of documentary cinema, neorealism, and a range of avant-garde, experimental filmmakers. He praises films by directors such as Dziga Vertov, Jean Vigo, and René Clair who respond to the speed, mobility, contingency, fragmentation, and constantly changing appearances of the modern world.

It is in this context that Kracauer's appreciation of Groteske should be situated. As early as the 1920s, Kracauer expresses his admiration for films by, amongst others, Mack Sennett, Roscoe "Fatty" Arbuckle, Harold Lloyd, Buster Keaton, and Charlie Chaplin. The French actor Max Linder and a number of lesser-known American comedians-Jimmy Aubrey, Clyde Cook, Harry Sweet, Larry Semon, Monty Banks, Joe Rock, Bobby Vernon, Lupino Lane, the Hall Room Boys, and the Little Rascalsnever failed to catch the critic's eye. Although he sporadically complains about the lack of creativity or innovation in films by these makers, his enthusiasm usually gains the upper hand, and their productions are often deemed better than the main feature included in the same film program. ${ }^{32}$ Kracauer frequently sings their praises in the concluding paragraph of a review about a feature film, but he also devotes standalone reviews to short films, including those by Linder, Chaplin, Lloyd, and Keaton. In his theoretical texts about film, slapstick comedy assumes a role from 1940 onwards; Kracauer contemplates it in the so-called Marseille notebooks (an outline developed in 1940 for a book on film aesthetics), which formed an early basis for his 1960 publication entitled Theory of Film, which also includes several passages on slapstick film, and he dedicates an entire article to silent-film comedy in the Monthly Film Bulletin in 1951.33

Like the avant-garde artists, Kracauer appreciates slapstick movies because they elevate motion and speed to an art form. "As for the pace, we can still learn much from the Americans," Kracauer writes in 1925. Such films are "a model of mobility" and offer "infinite variations on the pictorial motif of the chase." 34 In Theory of Film, he expresses his admiration for the rally or chase sequence, which he describes as a "complex of interrelated movements" and "motion at its most extreme, one might even say, motion as such." 55 Likewise, he praises Harold Lloyd, whom he calls a Geschwindigkeitsteufel or a "devil of velocity," and characterizes his films as being "consummate motion comedy without meaning." 36 Kracauer had previously discovered this trait in early French comedies such as La course des sergents en ville and La course

32. See, for example, Siegfried Kracauer, "Film-Kammerspiel" (1927), in Werke 6.1, pp. 360-61; and "Ariadne in Hoppegarten" (1928), in Werke 6. 2, p. 169.

33. The unpublished Marseille notebooks are preserved in the Deutsches Literaturarchiv in Marbach am Neckar. See Hansen, "With Skin and Hair," pp. 437-69. Siegfried Kracauer, "Silent Film Comedy," Monthly Film Bulletin 21, no. 1 (August-September 1951), pp. 31-32.

34. Siegfried Kracauer, "Aus der Gesellschaft" (1925), in Werke 6.1, p. 174.

35. Kracauer, Theory of Film, p. 42.

36. He calls Lloyd's films "ausgezeichnete Bewegungskomik ohne Sinn.” Siegfried Kracauer, "Alemania-Lichtspiele" (1923), in Werke 6.1, p. 33; and "Harold Lloyd" (1929), in Werke 6.2, pp. 184-85. 
des potirons (both 1907) that consisted of little more than a chase scene. The motif of the chase reaches its apogee for Kracauer in the Keystone comedies that Mack Sennett started producing in 1912: "For any Keystone comedy to forgo the chase would have been an unpardonable crime. It was the climax of the whole, its orgiastic finale - a pandemonium, with onrushing trains telescoping into automobiles and narrow escapes down ropes that dangled above a lion's den."37

For Kracauer, a second quality of slapstick comedy is its ability to breathe life into inanimate objects. In this respect, he considers slapstick humor to be eminently cinematic. The medium of film is unique in that it can, via close-ups, camera movements, and photographic effects, "bring the inanimate to the fore and make it a carrier of action." 38 Kracauer's fascination with cinema's power to animate lifeless objects is perfectly illustrated by "the malicious escalators, the unruly Murphy beds, and the mad automobiles" that invariably steal the show in a slapstick movie. Yet as objects come to life, the converse also occurs: People "acquire the attributes of objects." 39 In the world of slapstick comedy, humans have an "object-like” physiognomy-Keaton's "stone face" is but one striking example; Chaplin, too, is a reified man. Whereas Benjamin sees Chaplin as a figure that physically appropriates the fragmentation and alienation engendered by industrial technology, Kracauer views him more as a figure without a will or self-consciousness. ${ }^{40}$ Although in his review of The Gold Rush (1925) he praises Chaplin's humanism and his ability to appeal to a universal audience, Kracauer describes Chaplin's screen type as ein Loch (hole), a kind of empty figure out of which "the purely human radiates in disconnection." "In pathology," he adds, "this would be called split of ego, schizophrenia." 41 A great example of such a visual and mental fragmentation is the hall-of-mirrors scene in The Circus, in which Chaplin's character and the cop who is chasing him are unable to differentiate between their real selves and the multiple reflections in the mirrors. Here Chaplin expresses a split view of reality, one in which the normal relationships between things and people are disrupted. But it is precisely as a result of this, in Kracauer's view, that new configurations between man and the world are attained. "His helplessness is dynamite," Kracauer writes. ${ }^{42}$ In a world full of alienation, the emptiness of the Chaplin figure creates the conditions that enable the construction of a "new man."

In these films, the struggle between people and objects in the newly automated world is laid bare. ${ }^{43}$ "The principle of the Chaplinaden," Kracauer writes, "is

37. Kracauer, Theory of Film, p. 42.

38. Ibid., p. 45.

39. Kracauer, in a 1924 review of a film by the Hallroom Boys, in Werke 6.1, p. 91.

40. $\quad$ Siegfried Kracauer, "Chaplin” (1926), in Werke 6.1, pp. 269-70.

41. Ibid.

42. Ibid.

43. In a 1926 review of a film by Jimmy Aubrey (probably The Train Wreckers), Kracauer writes that slapstick comedies "expose a world of surfaces that reveals the difficult relationship between people and objects through comedy. We should be grateful to the Americans because they have conquered these spheres, which were predestined for film.” Siegfried Kracauer, in Werke, vol. 6.1, p. 187. 
always the same: the demonstration of the unreal and the desperate struggle with the mechanized world." 44 A film such as The Electric House (1922)—in which Buster Keaton tries to "automate" a house, with predictably disastrous results 45 demonstrates, in his view, "the vacuous and desperate struggle of people cut off from the reality with the mechanized world." 46 According to Kracauer, the "whole mechanized world is shown in a comical light by Chaplin and his companions, its seriousness resolved, its gravity transformed into pleasure; the nature of its movement is highlighted through exaggeration and ridicule." $47 \mathrm{He}$ describes the films as a "counterweight" to the reality of capitalist rationalization and mechanization: "If in that reality they subject the world to an often unbearable discipline, they dismantle this self-imposed order quite forcefully in film." 48

In the 1920s, Kracauer interprets the slapstick comedies as an anarchist critique of such logic, in the same way the Surrealists did. In his later texts, however, he shifts his emphasis to focus on the ways in which slapstick playfully but systematically confronts us with "material life at its crudest." 49 He compares the rhythm of slapstick films with the "sputtering of a machine gun" and writes that "the leitmotif of the slapstick comedy is the play with danger, with catastrophe" illustrated in countless daredevil stunts. ${ }^{50}$ Yet the spectacular feats and the numerous "last-minute rescues" have nothing to do with divine intervention or melodramatic coincidence; they are merely the result of chance. For Kracauer, this notion of chance is linked to a specific historical condition: that of a modern, industrialized mass society in which life, as played out in rapidly developing cities, has become unpredictable and volatile. On this point, Kracauer was aligned not only with the Dadaists and Surrealists via his interest in the accidental but also with the (neo)realistic aesthetics that he would later champion in Theory of Film. Before the era of studio-bound shooting, many comedies used city streets as open-air sets, placing actors in public settings. The exploitation of preexisting contexts helped to economize on budgets while still providing high production values, but many films-from Max Linder (Max toréador, 1913) to Mack Sennett comedies-took the aesthetics of chance interactions with an unpredictable and transitory crowd as their very theme. In Fatty and Mabel at the San Diego Exposition (1915), for instance, Roscoe "Fatty" Arbuckle and Mabel Normand test a selection of exhibits at the San Diego World's Fair, mingling with exhibitors and on-site visitors. The crowd responds to the disruptions with recognition and mirth, which gives center stage to an atmosphere of unrehearsed liveliness. Chance also structures slapstick's narratives; the films string together a loose succession of autonomous actions and

44. Siegfried Kracauer, "Die grosse Unbekannte (Teil II)" (1924), in Werke 6.1, p. 69.

45. Siegfried Kracauer, "Paris und Amerika" (1926), in Werke 6.1, p. 225.

46. $\quad$ Siegfried Kracauer, in a 1924 discussion of Laughing Gas (1914), in Werke 6.1, p. 69.

47. Siegfried Kracauer, "Lustspiel Potpourri” (1924), in Werke 6.1, pp. 64-65.

48. Siegfried Kracauer, “Artistisches und Amerikanisches” (1926), in Werke 6.1, p. 199.

49. Hansen, "With Skin and Hair," p. 460.

50. $\quad$ Siegfried Kracauer in his Marseille Notebooks, quoted in Hansen, "With Skin and Hair," p. 461. 
intermittent sequences of gags, opting for visual delight at the expense of narrative logic. Through this structure the films of Linder, Sennett, and early Chaplin reflect a condition marked by contingency and indeterminacy. It is in this sense that Kracauer, in his later years, refers to American silent-film comedies in the same context as neorealist cinema: "The streets in Umberto D. (1952) lead a life of their own; and the furniture, staircases, and cars in slapstick comedy behave exactly like actors in the flesh." 51 Not coincidentally, Kracauer criticizes Speedy (1928), starring Harold Lloyd, for having of "too much theme park" and "too much wildness," while lauding it for the location shooting. "What first and foremost touches us are the excellent shots of New York street life," he states. 52

\section{Adorno: Chaplin as Negation and Industrial Entertainment}

Adorno is far more skeptical than Kracauer and Benjamin about the utopian potential of film and of technology and mass culture in general. For Adorno, cinema is the ultimate embodiment of what he and Max Horkheimer famously described as the "culture industry," a condition in which culture has appropriated the cult of efficiency and structured planning of the industrialized societies. "Culture today is infecting everything with sameness" and "entertainment is the prolongation of work under late capitalism," argue Adorno and Horkheimer in Dialectic of Enlightenment. 53 Mass culture and particularly the film industry utilize

51. Kracauer, Theory of Film, p. 266.

52. $\quad$ Siegfried Kracauer, "Ballet, Jazz, Harold Lloyd" (1929), in Werke 6.2, p. 298.

53. Theodor W. Adorno and Max Horkheimer, Dialektik der Aufklärung: philosophische Fragmente (Amsterdam: Querido, 1946); in English as Dialectic of Enlightenment: Philosophical Fragments, trans. Edmund Jephcott (Stanford, CA: Stanford University Press, 2002), pp. 94 and 109.

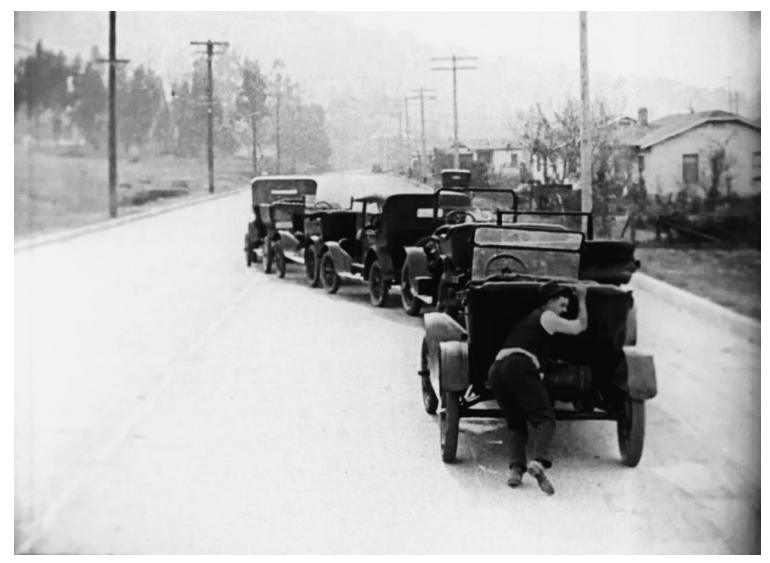

Del Lord. Super-Hooper-Dyne Lizzies. 1925. 
ready-made clichés and formulaic protocols, which result in "mechanically differentiated products" that "are ultimately all the same. That the difference between the models of Chrysler and General Motors is fundamentally illusory is known by any child, who is fascinated by that very same difference. . . . It is no different with the offerings of Warner Brothers and Metro Goldwyn Mayer." 54 Adorno and Horkheimer describe Orson Welles's innovations as a kind of "calculated rudeness" that confirms "the validity of the system all the more zealously." 55 Moreover, as he demonstrates in his essay "The Scheme of Mass Culture," film illustrates the regression of rationalized Western culture to the status of a myth. ${ }^{56}$ As does fascism, the Hollywood dream factory produces archaic symbols on an industrial scale. The themes of the reversal of the Enlightenment myth and the persistent presence of the archaic in the modern era are two of the connecting threads that run throughout Dialectic of Enlightenment.

Nevertheless, Adorno is often positive about film. Even the worst movies, he says, can contain occasional flashes of brilliance that are indicative of artistic potential. ${ }^{57}$ Various articles and letters also show that Adorno was a diligent cinemagoer, and one who maintained close contacts with filmmakers such as Fritz Lang. ${ }^{58}$ Within his texts and correspondence, Adorno also writes about slapstick films in highly favorable terms. He interprets the antics of the Marx Brothers, particularly the scenes in which they dismantle an opera stage set or a piano, as allegories of the decline of music and the regression of listening. ${ }^{59}$ Even Dialectic of Enlightenment contains remarkably mild statements about, for example, Chaplin and the Marx Brothers, who "fall back perniciously on the pure nonsense."60 Though the culture industries may have reduced laughter to a compulsory number within the entertainment repertoire, the crude and anarchic humor of "some revue films, and especially in some grotesque stories and funnies," still offers the potential for a momentary glimpse of the negation of the cruel conditions of capitalist modernity. ${ }^{61}$ For Adorno and Horkheimer, comedies are the "exponents of fantasy against rationalism." 62 In an essay about the schematization of our experiences by the culture

54. Adorno and Horkheimer, Dialectic of Enlightenment, p. 97.

55. Ibid., p. 102.

56. Theodor W. Adorno, "The Scheme of Mass Culture," in The Culture Industry: Selected Essays on Mass Culture (London: Routledge, 1991), p. 80.

57. Theodor W. Adorno, Composing for the Films (London: Athlone, 1994), p. xi.

58. See also Nicole Brenez, "Adorno: Cinema in Spite of Itself-But Cinema All the Same," Cultural Studies Review 13, no. 1 (March 2007), pp. 70-88.

59. Theodor W. Adorno, "On the Fetish Character in Music and the Regression of Listening," in The Culture Industry, p. 51.

60. Adorno and Horkheimer, Dialectic of Enlightenment, p. 109.

61. Ibid., p. 114.

62. Ibid., p. 110. 
industry, Adorno writes of his appreciation for the genre that was the breeding ground of slapstick cinema: the variety show that was made up of a series of short, sensational acts. ${ }^{63}$ The format presaged the gag structure of slapstick movies and determined the format of film programs before the hegemony of the narrative feature film, and it mirrors the "industrial procedures, mechanical repetition, and the temporality of the ever-same." 64 Adorno sees both the music hall and slapstick comedy as allegories of high capitalism in which the logic of instrumentalization is omnipresent. In his eyes, it was no coincidence that preeminent modernist artists, such as Wedekind, Cocteau, Apollinaire, and Kafka, were fascinated by variété. And like these avant-garde artists, Adorno appreciates the ability of the variety show to undermine public expectations through a combination of repetition and rhythmic predictability. Tellingly, Adorno even discerned the repetitive patterns of variety shows and slapstick comedies in the best of avant-garde art. In Aesthetic Theory, he also notes that Samuel Beckett's antiheroes appear to be borrowed from the world of slapstick cinema. 65 As in the plays by Beckett, who would collaborate with Buster Keaton on Film (1965), slapstick comedies tend to be populated with ahistorical characters who always end up in the same situations and are given no room for confrontation or reconciliation. 66

Despite his positive stance on certain aspects of slapstick films, Adorno demonstrates a marked ambivalence toward Chaplin. He is extremely critical of the social conformity of Chaplin's films, arguing that the audience's laughter gave them a false sense of liberation. Of Modern Times, Adorno writes that the film fails to provide any solutions to the contradictions that it evokes-in much the same way that Disney cartoons confirm the status quo. Writing to Benjamin, Adorno says: "The idea that a reactionary is turned into a member of the avant-garde by expert knowledge of Chaplin's films [as Benjamin seems to suggest] strikes me as out-and-out romanticization." 67 In his eyes, Chaplin was frequently guilty of aligning himself with the most vulgar effects of the culture industry. He considers The Great Dictator (1940) to be an unmitigated failure because of the way in which it dishes up the same imagery as Nazi propaganda: "The swaying cornfields at the end of Chaplin's film on Hitler give the lie to the anti-fascist speech about freedom. They resemble the blond tresses of the German maidens whose outdoor life in the summer wind is photographed by UFA."68

63. Adorno, "The Scheme of Mass Culture," pp. 60-61.

64. Hansen, Cinema and Experience, p. 239.

65. Theodor W. Adorno, Aesthetic Theory (London: Athlone, 1997), p. 81.

66. James Martin Harding, Adorno and a Writing of the Ruins: Essays on Modern Aesthetics and AngloAmerican Literature and Culture (Albany: State University of New York Press, 1997), p. 60.

67. Theodor W. Adorno, "Letter to Walter Benjamin" (March 18, 1936), in Theodor W. Adorno and Walter Benjamin, The Complete Correspondence 1928-1940 (Cambridge: Polity Press, 1999), pp. 13031.

68. Adorno and Horkheimer, Dialectic of Enlightenment, p. 119. 
Yet the work and the character of Charlie Chaplin also fascinated Adorno, as it did Benjamin and Kracauer. He describes Monsieur Verdoux (1947) as a masterpiece, and on several occasions he mentions Chaplin in the same breath as Beckett or Karl Kraus. ${ }^{69}$ According to Adorno, Chaplin makes "mechanization into a privileged theme" and transforms the "shock of the ever same into a Bergsonian laughter."70 In line with Henri Bergson, who defined humor as being occasioned by "something mechanical in something that is alive," he perceives Chaplin as being a specific physical construction linked to the modern, technology-driven medium of film. ${ }^{71}$ "Nowhere but on the screen could this enigmatic figure . . . have developed its concept," Adorno writes. ${ }^{2}$ Furthermore, he appreciates the way in which Chaplin sabotages the logic of sound in Modern Times (1936), a talkie in which images are usually subservient to spoken dialogue. ${ }^{73}$

Finally, it is not unimportant that when in exile in California in the 1940s, Adorno was in personal contact with Chaplin and enjoyed socializing with him. In his autobiography, he recounts that he and his wife attended a private screening of Monsieur Verdoux with the famous comedian. After dinner, Adorno played the piano while Chaplin humorously accompanied him. In another text, Adorno describes a dinner in 1946 at which he sat next to the famous comedian. ${ }^{74}$ That night, Adorno is introduced to the actor Harold Russell, who had lost both of his hands during the war and is wearing metal prostheses. The philosopher shakes the actor's hand and is startled by the sensation. Anxious to appear polite, he abruptly switches his horrified expression into an obliging grimace, which Chaplin deftly imitates. Adorno uses the anecdote to illustrate the fact that Chaplin's humor was based on mimicry: "All the laughter he brings about is so near to cruelty; solely in such proximity to cruelty does it find its legitimation and its element of the salvational."75 It is no coincidence that a prosthetic limb played an important role in this anecdote-both Benjamin and Kracauer also praise Chaplin as a comedian who capitalizes on the logic of industrial modernity via his mechanical body language and fractured physicality.

69. Stefan Müller-Doohm, Adorno: A Biography (Cambridge: Polity, 2009), p. 312.

70. Adorno, "The Scheme of Mass Culture," pp. 61-62.

71. Henri Bergson, Le rire: Essai sur la signification du comique (1900; Paris: Éditions Alcan, 1924).

72. Theodor W. Adorno, "Transparencies on Film," in The Culture Industry, p. 155. Adorno also nuances Chaplin's "filmic" nature by stating that Chaplin was either unaware or purposely ignored cinematic techniques, "being content with the photographic rendering of sketches, slapstick routines, or other performances." This tallies with the opinions of many film critics who found Chaplin inferior to Buster Keaton as a director and "film artist." Both Adorno and Benjamin, however, refer to Chaplin's style of acting as inherently marked by the cinematic apparatus, not to his style of directing.

73. Ibid., p. 81.

74. Theodor W. Adorno, "Chaplin Times Two," The Yale Journal of Criticism 9, no. 2 (Spring 1996), pp. 57-61. See also Anca Parvulescu, Laughter: Notes on a Passion (Cambridge, MA: MIT Press, 2010), p. 151.

75. Adorno, "Chaplin Times Two," pp. 60-61. See also Jennifer Bean, "The Art of Imitation: The Originality of Charlie Chaplin and Other Moving-Image Myths," in Slapstick Comedy, ed. Tom Paulus and Rob King (London: Routledge, 2010), pp. 236-61. 
Chaplinism, Anachronism, and Nostalgia

Like many other leftist intellectuals, Adorno, Benjamin, and Kracauer fêted Chaplin in particular. This preference is not unrelated to Chaplin's own sympathies for the progressive forces in the political arena. As early as the 1920s, Chaplin's films were viewed as social critiques for their far-reaching depictions of modern life, including poverty, unemployment, injustice, and violence. ${ }^{76}$ In several of his writings of the late 1920s and early '30s, Kracauer, for instance, emphatically praises Chaplin's ability to appeal to the masses. "He fulfills the wonder that kings no longer can achieve: abolishing the opposition between classes by his mere presence, creating a truce between all parties" and finding himself "Jenseits der Politik" or "beyond politics."77 Furthermore, Chaplin has proved himself to be "a friend of the powerless, of the unfortunate and, with his good heart and sharp eyes, he analyzes our social jungle," according to Kracauer. ${ }^{78}$ Leftist intellectuals, no doubt, were also fascinated by the ways Chaplin mocks and undermines social authority, invariably ridiculing "that silly multi-headed beast, the police."79

The appreciation of Chaplin among the Frankfurt theorists is, however, somewhat ironic because his films do not always provide the most obvious illustrations of the aspects of slapstick comedy that they admire the most. In this, there is a striking anachronism. The "positive" qualities of slapstick recognized in Frankfurt critical theory are much more clearly reflected in the early short films that Mack Sennett produced in the 1910s or Chaplin's early short comedies than in his feature films of the 1920s and '30s. While Chaplin's early short films are particularly characterized by raw violence, physical aggression, and social subversion, the later and longer films - those upon which Benjamin and Adorno largely base their arguments-are distinguished by an increasing narrative integration, greater sentimentality, and the romantic image of the Tramp. The film model that Benjamin, Kracauer, and Adorno have in mind is not so much that of the classic feature film (to which Chaplin's work from 1921's The Kid onward increasingly responds), but rather that of the pre-classic "cinema of attractions." 80 The jerky rhythm of gags that they describe is reminiscent more of the edited program in a variété show than of the narrative structure of the conventional theater, and compact, joke-based movies fit much more easily into

76. Hake, "Chaplin Reception in Weimar Germany," p. 96; Thomas J. Saunders, Hollywood in Berlin: American Cinema and Weimar Germany (Berkeley: University of California Press, 1994), pp. $186-92$.

77. Siegfried Kracauer, "Chaplins Triumph" (1931), in Werke 6.2, p. 492. See also "Chaplin kommt an!” (1931), in Werke 6.2, pp. 468-70.

78. $\quad$ Siegfried Kracauer, "Lichter der Grosstadt" (1931), in Werke 6.2, p. 472.

79. Siegfried Kracauer, "Lustspiel-Potpourri” (1924), in Werke 6.1, p. 64.

80. See Tom Gunning, "The Cinema of Attraction: Early Film, Its Spectator, and the AvantGarde" (1986), in Early Cinema: Space, Frame, Narrative, ed. Thomas Elsaesser (London: BFI, 1990), pp. 56-62. 
Kracauer's notion of distraction or Benjamin's conception of shock than do the titles they typically cite. Although short slapstick-comedy films were still produced in the 1920s and '30s, the comedic cinema of the post-WWI era was first and foremost associated with feature-length "comedian-comedies" by Chaplin, Keaton, Lloyd, and Langdon-a model that was already dominant when Adorno, Benjamin, and Kracauer wrote their seminal texts on cinema including their celebrations of slapstick comedy. Benjamin's earliest references to Chaplin date from the late 1920s, and when titles of films are explicitly mentioned (such as The Circus), they are of films from the '20s and '30s. Likewise, Adorno discusses only the Marx Brothers and Chaplin films from the sound era. Nonetheless, all three critics analyze and cherish the characteristics that marked early slapstick cinema. Their somewhat anachronistic take on Chaplin may, of course, be a result of the fact that Chaplin's films were not shown in Germany until 1921 and that even then, only a limited selection of the very early short comedies were available and shown indiscriminately in conjunction with his later feature films. ${ }^{81}$ It is possible they had seen early French slapstick comedies (to which Kracauer refers in his Theory of Film) before the First World War, but they probably saw feature-length films such as The Kid (1921) and The Gold Rush (1925) and some two-reelers of the early 1920s before having knowledge of the early Chaplin shorts produced by Keystone, Essanay, and Mutual. This resulted in a hybrid persona that merges the "sentimental" Chaplin with the more anarchic Tramp character. Kracauer, who wrote about slapstick film earlier than Benjamin and Adorno and who also discusses many other slapstick comedians, was certainly aware of the differences between the early and later Chaplin. In several reviews, he mentions reruns or rereleases of older Chaplin films. ${ }^{82}$ In 1927, for example, he notes that Chaplin's older films can still be seen in Paris, whereas only a handful of examples are screened in Germany. ${ }^{83}$ He applauds the Chaplin of the 1910s, who is "entirely in the style of the old Groteske" and who is still "an artist who does not long for self-reflexivity." The world depicted in these older Chaplin films may have disappeared, but the cane, the shoes, and the Tramp costume move through space as young as ever. ${ }^{84}$

Despite the subversive and utopian dimensions attributed to slapstick cinema, Chaplin, for Kracauer, evokes "a charming indecisiveness, like childhood," and his image is inherently connected with a feeling of nostalgia for a bygone

81. Hake, "Chaplin Reception in Weimar Germany," pp. 89-90.

82. See, for instance, Siegfried Kracauer, "Die grosse Unbekannte (Teil II)" (1924), in Werke 6.1, p. 69; "Alte Chaplinfilme" (1927), in Werke 6.1, p. 421; "Zwei alte Chaplinfilme" (1928), in Werke 6.2, p. 28; "Chaplin vor einem Jahrzehnt" (1928), in Werke 6.2, p. 41; "Chaplin in Carmen" (1929), in Werke 6.2, pp. 204-05; "Chaplin als Prediger" (1929), in Werke 6.2, pp. 312-14; and "Chaplin in alten Filmen" (1930), in Werke 6.2, pp. 339-40.

83. Kracauer, “Alte Chaplinfilme,” p. 421.

84. Kracauer, "Chaplin in alten Filmen," pp. 339-40. 
era. ${ }^{85}$ While Chaplin perfectly embodies and symbolizes the contemporaneous mechanized and Taylorized world, he keeps radiating the picturesque settings of Victorian London-both Benjamin and Kracauer explicitly connect Chaplin with Dickens. ${ }^{86}$ The aging of Chaplin as a person is connected to the growing obsolescence of silent slapstick cinema. Benjamin, in his 1929 retrospective "Rückblick" article on Chaplin, notes that "The Circus is the first product of the art film that is also the product of old age. Charlie has grown older since his last film. But he also acts old." 87 Adorno describes Chaplin in 1930 "like a ghostly photograph in a liveaction film." 88 In Transparencies on Film, written in 1966, he states that Chaplin was "reminiscent of old-fashioned photographs right from the start." 89

The nostalgic view of slapstick film that permeates Kracauer's and Adorno's postwar writings is not unlike other postwar reinterpretations and reappropriations of slapstick cinema. Kracauer's 1951 Monthly Film Bulletin article "Silent Film Comedy," which summarizes many of the topics dealt with in his earlier writings, is similar to James Agee's seminal 1949 Life article entitled "Comedy's Greatest Era," which reframes slapstick comedy as the lost art of silent pantomime. 90 The publication of these articles also coincides with book-length publications by Parker Tyler and Robert Payne that presented Chaplin as a mythical figure. ${ }^{91}$ Like Adorno, both Agee and Tyler praise Chaplin's Monsieur Verdoux (1947), although the film signals that "the world's most popular film character was forever gone" and that the silent era was definitely over. ${ }^{92}$ From the late 1940 s onward, slapstick's repositioning is cemented by a series of rereleases in theaters and on home movie formats, the editing of compilation films made from short clips, the production of feature films set in the silent slapstick era, and the broadcasting of edited shows

85. Ibid.

86. See Walter Benjamin, "Rückblick auf Chaplin" (1929), in Gesammelte Schriften 3, pp. 15759; published in English as "Chaplin in Retrospect," in Kaes, Baer, and Cowan, The Promise of Cinema, p. 400; and Siegfried Kracauer, "Chaplin" (1928), in Werke 6.2, p. 168.

87. Benjamin, "Rückblick auf Chaplin," pp. 157-59; "Chaplin in Retrospect," pp. 398-400.

88. Theodor W. Adorno, "Kierkegaard prophezeit Chaplin" (1930), published in English as "Prophesied by Kierkegaard," The Yale Journal of Criticism 9, no. 1 (1996), p. 58; also included in Kaes, Baer, and Cowan, The Promise of Cinema, pp. 401-02.

89. Theodor W. Adorno, "Transparencies on Film" (1966), in The Culture Industry, p. 155.

90. Siegfried Kracauer, "Silent Film Comedy," Monthly Film Bulletin (August-September 1951), pp. 31-32; James Agee, "Comedy's Greatest Era," Life (September 5, 1949), pp. 70-89, also included in Agee on Film: Criticism and Comment on the Movies (New York: Modern Library, 2000), pp. 391-412.

91. See Parker Tyler, Chaplin: Last of the Clowns (New York: Vanguard, 1948); and Robert Payne, The Great God Pan: A Biography of the Tramp Played by Charlie Chaplin (New York: Hermitage House, 1952). Kracauer reviewed Tyler's book in "Portrait in Film" (1948), in Siegfried Kracauer's American Writings, pp. 188-90. See also Adrian Martin, "The Dream Team: The Parker Tyler and Siegfried Kracauer Correspondence," Cineaste 40, no. 1 (Winter 2014), pp. 20-25.

92. See David Bordwell, The Rhapsodes: How 1940s Critics Changed American Film Culture (Chicago: University of Chicago Press, 2016), p. 127. 


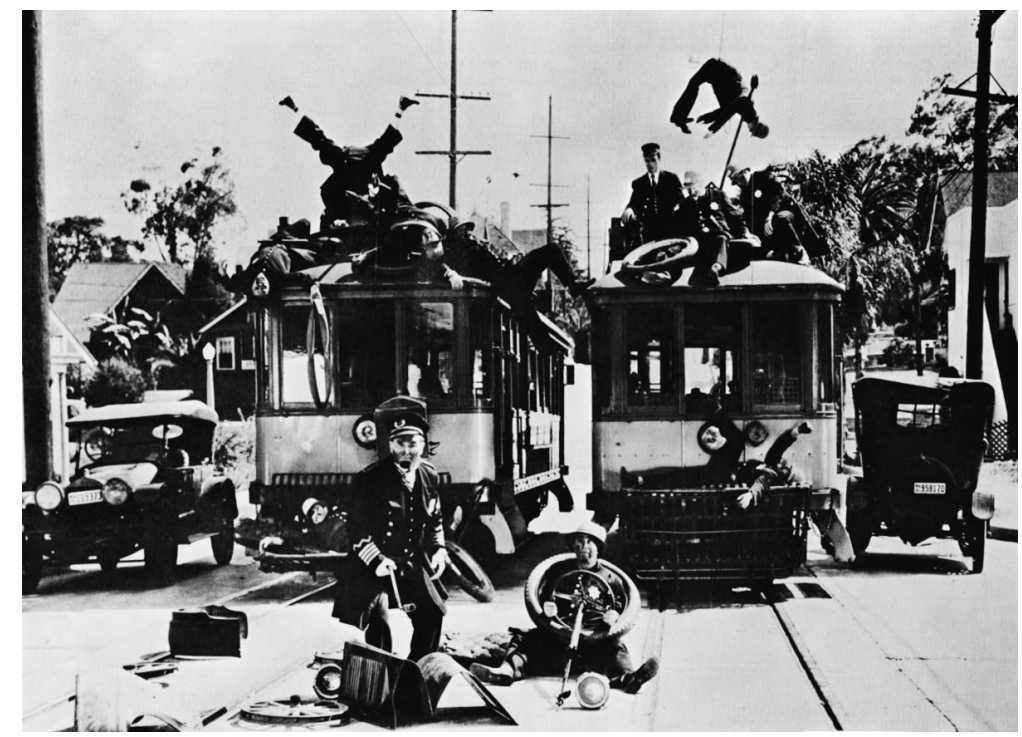

Irving Cummings and Mal St.Clair.

Hollywood Cavalcade. 1939.

and reruns on TV.93 In television shows and compilation films, snippets of 1920s films by various slapstick comedians are detached from their original contexts and edited as a fast-paced succession of gags. In damaged, incomplete, or substandard prints, story lines tend to get blurred, leaving only strings of gags. In the process, fragments of the more narrative-oriented productions of the 1920s are recombined with early gags, greatly confusing the temporality of the reviewed slapstick films. Though it was originally connected to utopian aspirations, slapstick comedy now becomes déclassé, increasingly associated with silly nostalgia, cheap recycling, and commercial appropriation. Paradoxically, however, these forms of appropriation result in highly fragmented film forms reminiscent of the earliest jerky slapstick comedies, the films favored by the avant-garde as well as the philosophers of the Frankfurt School.

93. Examples include Hollywood Cavalcade (1939, dir. Irving Cummings), which features a blackand-white sequence in which some of the original Keystone Cops and Buster Keaton reenact a chase filmed by slapstick veteran Mal St. Clair, and Down Memory Lane (1949, dir. Phil Karlson), a compilation with narration of silent Mack Sennett comedies. Later, National Telepix, Inc., broadcasted "Mischief Makers" (1960-61) and "Comedy Capers" (1961-62), silent comedies edited down and repackaged for children. 